\title{
DEFECTS DETECTION IN THE FIRST MANUFACTURED MODULE - ENSURING ERRORS FLOW IN THE GARMENT MANUFACTURING PROCESS
}

\author{
Sanja Risteski*, Vineta Srebrenkoska, Stefan Maksimov
}

University “Goce Delčev", Shtip, Faculty of Technology,

Norh Macedonia

*e-mail: sanja.risteski@ugd.edu.mk
Professional paper

UDC: $687+658.5 .005 .4$

doi: $10.5937 /$ tekstind2002018R

Abstract: Quality control is necessary quality management activity. It doesn't create values but it contributes to more successful work in the company. It ensures that the tasks set out in the plan are accomplished in a timely, rational and cost-effective manner. In this paper an approach to assessing the quality of the first manufactured module in the production of clothes is made. Defects that reduce the use value of clothes, and their frequency caused because of a poor quality were detected. With use of Ishikawa diagram, the causes for defects occurrence were identified, and their elimination was initiated.

Key words: quality, costs, errors, control.

\section{ODREĐIVANJE DEFEKTA U PRVOM PROIZVODNOM MODULU - OBEZBEDITI SE OD POJAVE OŠTEĆENJA U PROCESU PROIZVODNJE ODEĆE}

Apstrakt: Kontrola kvaliteta je neophodna aktivnost upravljanja kvalitetom. To ne stvara vrednosti, već doprinosi uspešnom radu u kompaniji. Kontrola kvaliteta omogućava da se zadaci u radnom planu izvršavaju na vreme, racionalno i ekonomično. U ovom radu je dat pristup proceni kvaliteta prvog proizvedenog modula u proizvodnji odeće. Otkriveni su nedostaci koji smanjuju upotrebnu vrednost odeće i njihovu učestalost uzrokovanu lošim kvalitetom. Upotrebom Ishikava dijagrama identifikovani su uzroci pojave grešaka i njihovo otklanjanje.

Ključne reči: kvalitet, troškovi, greške, kontrola.

\section{INTRODUCTION}

In the past, quality was considered as a task of the final control, which means that at the end of the production process the controllers separate the defective products from the quality ones. However, over the time this system proved to be slow and expensive, because controlling the products only at the end of the production process can result with a higher number of defective products, and that can lead to a quality products obtaining, but at higher price. The next stage in the control development is focused to prevent defects occurrence, which imposes control at all stages of the technological process. With this approach, any omissions related to machines, man, raw materials can be detected and actions for solving can be made. Contemporary control is focused on a defects prevention $[1,2,3]$.

Because the quality of a product is created during the production process, it is necessary: 
$\checkmark$ To form a complex of business processes, starting from the entry of raw materials to a finished product;

$\checkmark$ To select methods for examining the working process;

$\checkmark$ To select methods and instruments for the working process;

$\checkmark$ Determine the control, depending of the working process, in other words to find the quality indicators - what should to be controlled;

$\checkmark$ The standardization of the meaning of those indicators, the category of defects, etc;

$\checkmark$ To determine the liabilities of the control, that are terms of the operators and controllers;

$\checkmark$ To implement verification method and methods for verifying regulations and measuring instruments. To indicate those places that are subject to statistical regulation by applying control cards as well as the type of control card;

$\checkmark$ To determine the methods and measures for action if deviations occur;

$\checkmark$ Prepare a control card for the quality of business processes in which all technological operations are given, each stage of production and the quality of work in it is considered, but taking care to choose the appropriate instrument to achieve proper control $[4,5,6]$.

In this paper is made an approach to assess the quality of the first production module, in the clothes production. Detecting certain defects, which reduced the use value of clothing, and have serious impact in the overall costs caused due to a poor quality, was also made. With the use of Ishikawa diagram, the causes of defects occurrence were determined, and their elimination was approached $[7,8,9]$.

\section{EXPERIMENTAL}

The model of women skirt that is subject to this analysis is shown below (Fig. 1).
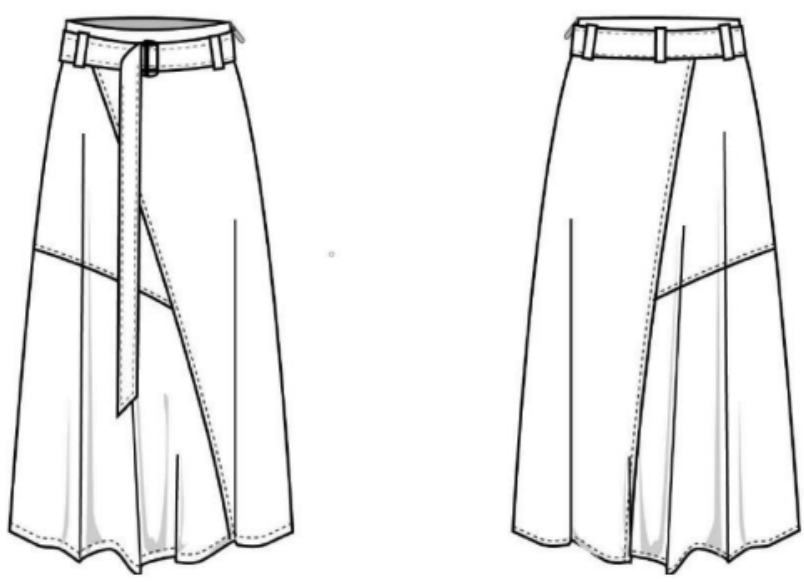

Figure 1: Front and rear part of the women skirt

In the process of the model production, was made an approach to quality control of the first manufactured module. According to the company's standard operating procedures, when a new model gets in the production line, accessed to the so-called production of the first module, which always amounts to $1.5 \%$ of the total order, which means one level below the specified level of acceptable quality (AQL) in the company, which is $2.5 \%$. During the production of this first module, the technologist together with the line controllers have the task to detect possible defects in the performance of each technological operation. Based on the received information, the production technologist is obligated to analyze and eliminate the possible causes for the occurrence of the registered defects.

Table 1 shows the work order, which defines the number of ordered pieces, the number of pieces from the first manufactured module as well as other informations that are an integral part of the work order.

Table 2 shows the plan of technological operations for the preparation of the model of women skirt.

Table 1: Work order of the women skirt

\begin{tabular}{|l|c|c|c|c|c|c|c|c|}
\hline Size & $\mathbf{3 2}$ & $\mathbf{3 4}$ & $\mathbf{3 6}$ & $\mathbf{3 8}$ & $\mathbf{4 0}$ & $\mathbf{4 2}$ & $\mathbf{4 4}$ & Total \\
\hline Pre-production example & $/$ & 1 & 3 & 1 & $/$ & $/$ & $/$ & $\mathbf{5}$ \\
\hline Pre-order 99869 & 17 & 153 & 258 & 237 & 201 & 152 & 54 & $\mathbf{1 0 7 2}$ \\
\hline First production module & $/$ & 2 & 4 & 4 & 3 & 2 & 1 & $\mathbf{1 6}$ \\
\hline
\end{tabular}


Table 2: Plan of technological operations for the preparation of the model

\begin{tabular}{|c|c|c|c|}
\hline $\begin{array}{c}\text { Number } \\
\text { of } \\
\text { operation }\end{array}$ & $\begin{array}{l}\text { Type of } \\
\text { operation }\end{array}$ & $\begin{array}{l}\text { Type } \\
\text { of } \\
\text { stitch }\end{array}$ & $\begin{array}{c}\text { Time of } \\
\text { manufacture }\end{array}$ \\
\hline \multicolumn{4}{|c|}{ Fixing } \\
\hline 1.1 & Fixing loops & I & 0,25 \\
\hline 1.2 & Fixing belt & I & 0,25 \\
\hline 1.3 & $\begin{array}{l}\text { Fixing movable } \\
\text { belt }\end{array}$ & I & 0,25 \\
\hline 1.4 & $\begin{array}{l}\text { Fixing seam under } \\
\text { the zipper }\end{array}$ & / & 0,25 \\
\hline \multicolumn{4}{|c|}{ Loops } \\
\hline 2.1 & Making loops & 301 & 0,55 \\
\hline 2.2 & $\begin{array}{l}\text { Interphase ironing } \\
\text { of the seam } \times 5\end{array}$ & 1 & 0,35 \\
\hline 2.3 & Turning loops x 5 & I & 0,90 \\
\hline 2.4 & Ironing loops & 1 & 0,30 \\
\hline 2.5 & Cutting loops & I & 0,45 \\
\hline \multicolumn{4}{|c|}{ Movable belt } \\
\hline 3.1 & $\begin{array}{l}\text { Movable belt } \\
\text { making }\end{array}$ & 301 & 1,95 \\
\hline 3.2 & $\begin{array}{l}\text { Cutting the } \\
\text { reserve of the belt } \\
\text { on the corners and } \\
\text { turning }\end{array}$ & I & 0,98 \\
\hline 3.3 & Ironing belt & I & 0,90 \\
\hline 3.4 & $\begin{array}{l}\text { Making decorative } \\
\text { stitch }(0,5 \mathrm{~cm} \\
\text { around) }\end{array}$ & 301 & 1,80 \\
\hline 3.5 & $\begin{array}{l}\text { Sewing belt } \\
\text { buckle for belt to } \\
\text { toil through }\end{array}$ & 301 & 1,22 \\
\hline \multicolumn{4}{|c|}{ Belt } \\
\hline 4.1 & $\begin{array}{l}\text { Sewing brand } \\
\text { label }\end{array}$ & 301 & 1,12 \\
\hline 4.2 & $\begin{array}{l}\text { Ironing belt }(1,0 \\
\mathrm{cm} \text { and then on } \\
\text { half) }\end{array}$ & / & 0,85 \\
\hline \multicolumn{4}{|c|}{ Front part } \\
\hline 5.1 & $\begin{array}{l}\text { Sewing upper and } \\
\text { bottom right part }\end{array}$ & $\begin{array}{l}301 . \\
504\end{array}$ & 0,48 \\
\hline 5.2 & $\begin{array}{l}\text { Making decorative } \\
\text { stitch }(0,5 \mathrm{~cm} \\
\text { around) }\end{array}$ & 301 & 0,40 \\
\hline 5.3 & $\begin{array}{l}\text { Sewing upper and } \\
\text { bottom front part }\end{array}$ & $\begin{array}{l}301 . \\
504\end{array}$ & 0,69 \\
\hline
\end{tabular}

\begin{tabular}{|c|c|c|c|}
\hline 5.4 & $\begin{array}{l}\text { Making decorative } \\
\text { stitch }(0,5 \mathrm{~cm} \\
\text { around })\end{array}$ & 301 & 0,58 \\
\hline 5.5 & $\begin{array}{l}\text { Overlock the side } \\
\text { seams }\end{array}$ & 504 & 0,67 \\
\hline 5.6 & $\begin{array}{l}\text { Sewing loops } \\
\text { on the marked } \\
\text { position }\end{array}$ & 301 & 0,54 \\
\hline \multicolumn{4}{|c|}{ Rear part } \\
\hline 6.1 & $\begin{array}{l}\text { Sewing upper and } \\
\text { bottom right part }\end{array}$ & $\begin{array}{r}301 . \\
504\end{array}$ & 0,48 \\
\hline 6.2 & $\begin{array}{l}\text { Making decorative } \\
\text { stitch }(0,5 \mathrm{~cm} \\
\text { around) }\end{array}$ & 301 & 0,40 \\
\hline 6.3 & $\begin{array}{l}\text { Sewing upper and } \\
\text { bottom rear part }\end{array}$ & $\begin{array}{r}301 . \\
504 \\
\end{array}$ & 0,69 \\
\hline 6.4 & $\begin{array}{l}\text { Making decorative } \\
\text { stitch }(0,5 \mathrm{~cm} \\
\text { around })\end{array}$ & 301 & 0,58 \\
\hline 6.5 & $\begin{array}{l}\text { Overlock the side } \\
\text { seams }\end{array}$ & 504 & 0,67 \\
\hline 6.6 & $\begin{array}{l}\text { Sewing loops } \\
\text { on the marked } \\
\text { position }\end{array}$ & 301 & 0,54 \\
\hline \multicolumn{4}{|c|}{ Montage } \\
\hline 7.1 & Sewing side seams & 301 & 1,65 \\
\hline 7.2 & Ironing the seams & 301 & 0,95 \\
\hline 7.3 & Sewing belt & 301 & 2,43 \\
\hline 7.4 & Sewing zipper & 301 & 2,95 \\
\hline 7.5 & Closing the zipper & 301 & 3,97 \\
\hline 7.6 & $\begin{array}{l}\text { Sewing label } \\
\text { (sustenance) }\end{array}$ & 301 & 0,25 \\
\hline 7.7 & Sewing label (size) & 301 & 0,25 \\
\hline 7.8 & $\begin{array}{l}\text { Sewing loops ( } 1,0 \\
\mathrm{~cm} \text { from the upper } \\
\text { side of the belt) }\end{array}$ & 301 & 1,65 \\
\hline 7.9 & Overlock the hem & 504 & 1,03 \\
\hline 7.10 & $\begin{array}{l}\text { Single tuck and } \\
\text { iron the hem }\end{array}$ & $/$ & 1,20 \\
\hline 7.11 & Stitching the skirt & 301 & 1,12 \\
\hline \multicolumn{4}{|c|}{ Finishing operations 1,20} \\
\hline 8.1 & $\begin{array}{l}\text { Cleaning the extra } \\
\text { thread }\end{array}$ & 1 & 1,20 \\
\hline 8.2 & $\begin{array}{l}\text { Control of finished } \\
\text { garment }\end{array}$ & $/$ & 1,95 \\
\hline
\end{tabular}

\section{RESULTS AND DISCUSSION}

The obtained results from the control during the production of the first module are shown in Table 3. 
Table 3: Check list of observed defects and their amount in the total number of defects

\begin{tabular}{|c|l|c|c|c|}
\hline $\begin{array}{c}\text { Serial } \\
\text { number }\end{array}$ & \multicolumn{1}{|c|}{ Type of defects } & $\begin{array}{c}\text { Number of } \\
\text { defects }\end{array}$ & $\begin{array}{c}\text { Detected defects from } \\
\text { the total number of } \\
\text { defects (\%) }\end{array}$ & $\begin{array}{c}\text { Cumulative } \\
\text { Percentage } \\
(\%)\end{array}$ \\
\hline 1 & Irregularly sewn (attached) loop & 1 & 5 & 5 \\
\hline 2 & Irregular width of the hem & 1 & 5 & 10 \\
\hline 3 & Holes on the side seam & 15 & 75 & 85 \\
\hline 4 & Crease on the zipper seam & 1 & 5 & 90 \\
\hline 5 & $\begin{array}{l}\text { Glaze on seams (movable belt) from } \\
\text { ironing }\end{array}$ & 2 & 10 & 100 \\
\hline Total & & $\mathbf{2 0}$ & & \\
\hline
\end{tabular}

From the obtained results (shown in Table 3) can be noticed that the largest percentage of registered defects in the first manufactured module, as much as $75 \%$ belong to the defect - holes on the side seam, which occurs at the preparation of the technological operation under serial number 7.1.

The number of defects in the technological operation 3.3 (belt ironing) is also high and it occurs immediately after finishing the technological operation 3.3. Other defects that occur with insignificant proportions are as follows: Irregularly sewn (attached) loop (technological operation 7.8), Irregular width of the hem (technological operation 7.11) and crease on the zipper seam (technological operation 7.4). impact on the process of production of women's skirt, and are possible causes of the defects that have the largest role.

One of the possible factors (for the occurrence of the defect holes on the side seam) is the machine, respectively adjustment and needle (Figure 3 ). For the preparation of the technological operation 7.1 (sewing side seams) was made the wrong choice of needle size as well as the wrong choice of transport gears during machine setup. The defect is shown on Figure 2.

To test whether the wrong choice of needle size and the wrong choice of transport gears are the main causes for the defect (holes in the side seam), new samples were sewn. It was selected a type of needle
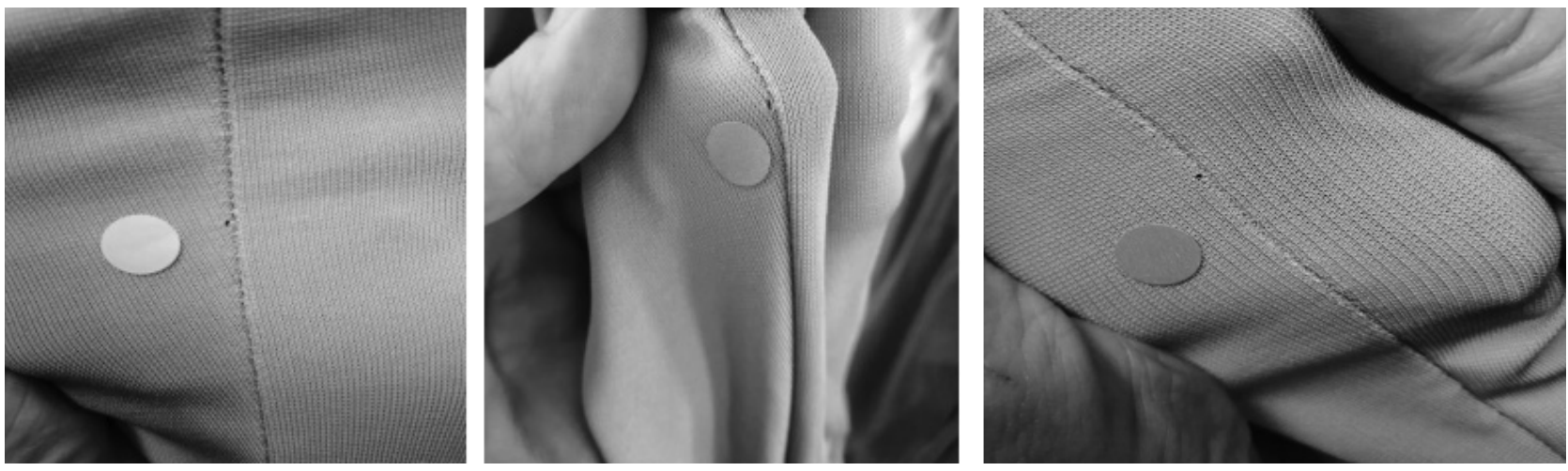

Figure 2: Holes on side seam defect

The defect holes on the side seam occur in almost all manufactured pieces of the first module intended for testing. This is warning for an unstable flow of production and production of low-quality products. In order to eliminate this defect, the most important thing is to detect the causes that lead to his occurring, as well as finding an appropriate solution. For that purpose, the Ishikawa diagram (Figure 3 ) has been applied, which presents all the factors that have an with a medium sphere head and needle with numeration $\mathrm{Nm} 65 . / 9$, instead of the previously used needle with numeration $\mathrm{Nm} 75 / 11$ with normal conic head. The transport gears with higher density and lower inclination were also applied (Figure 4). The pattern of the seam sewn with a new machine settings is shown on Figure 5. 


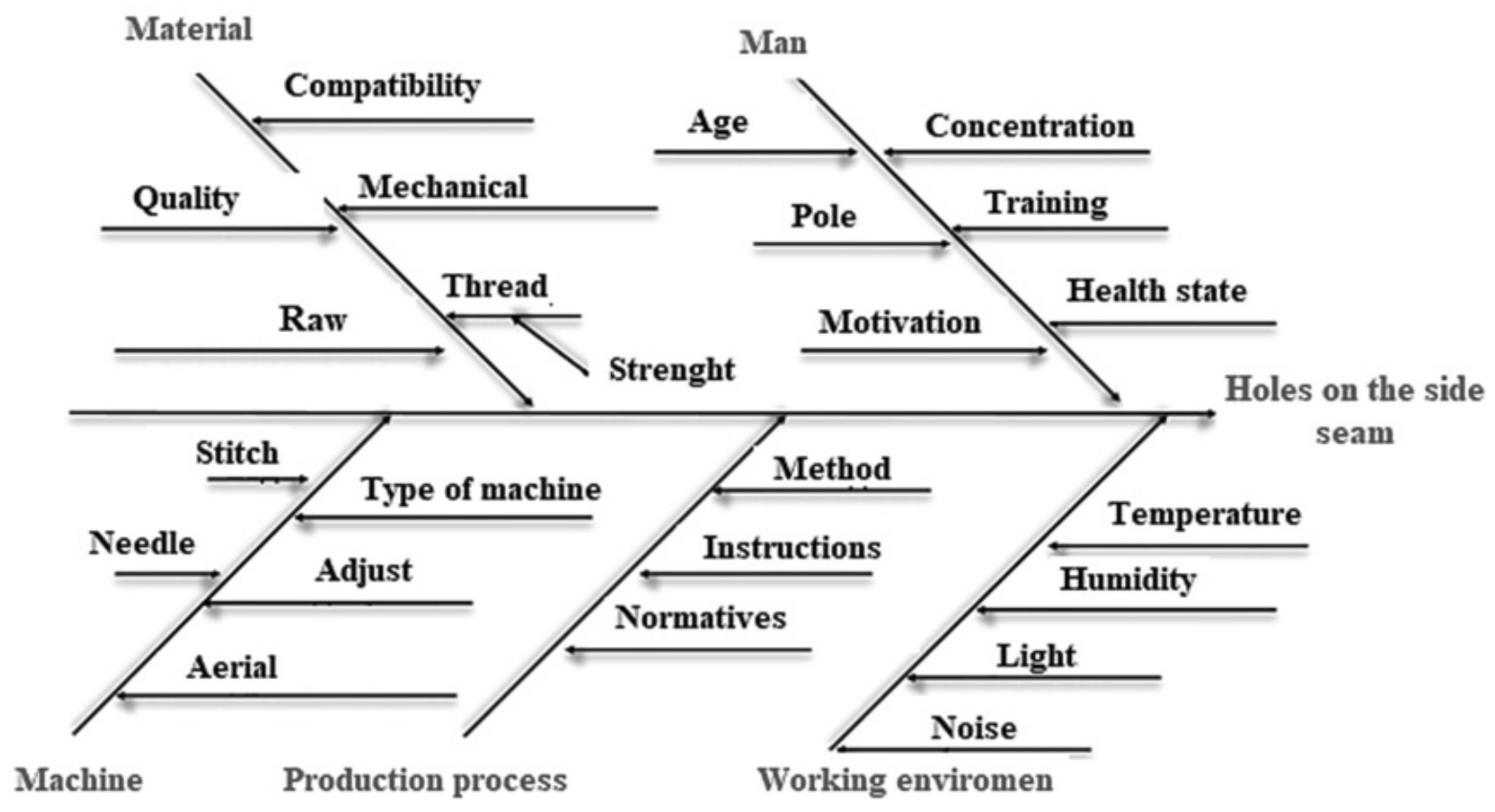

Figure 3: Ishikawa diagram for the operation holes on the side seam

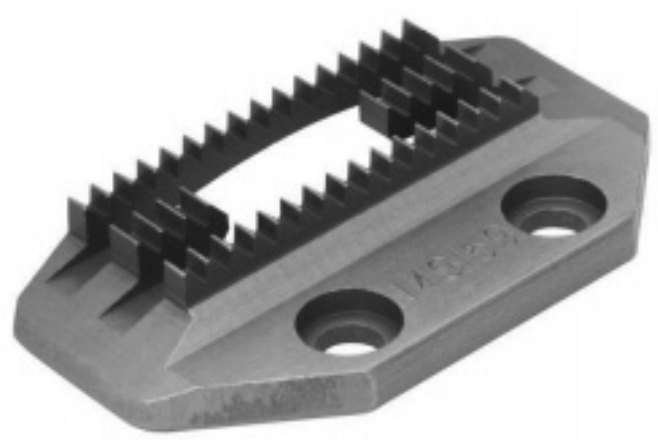

a)

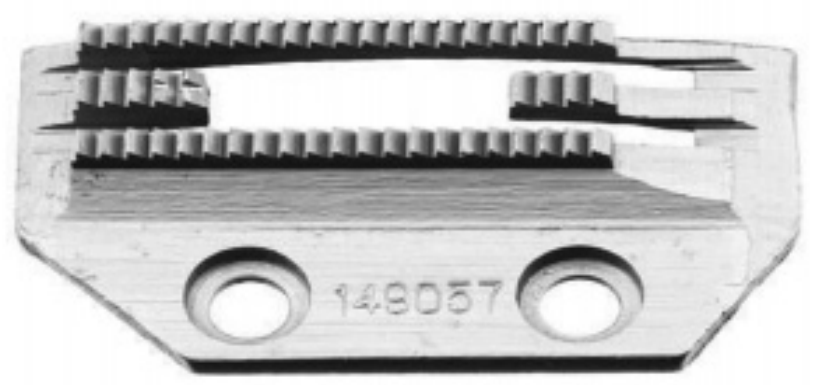

b)

Figure 4: Transport gears

a) producing defects on the sample b) producing no defects

For the other defects occurring, it was noticed that the main cause is the man. That indicates that the line controllers should pay more attention in controlling operators who are working on these operations, to achieve a stable and quality course of the production process without variations for defects repair.

In addition, Table 4 shows the registered defects in the final production control. With the application of inter-phase control and control in the first manufacture module, the detected defective products did not exceed $2 \%$ of the total produced pieces of women's skirt. This indicates a steady flow of production process, without additional operating losses due to poor quality, caused by machines, materials and man.

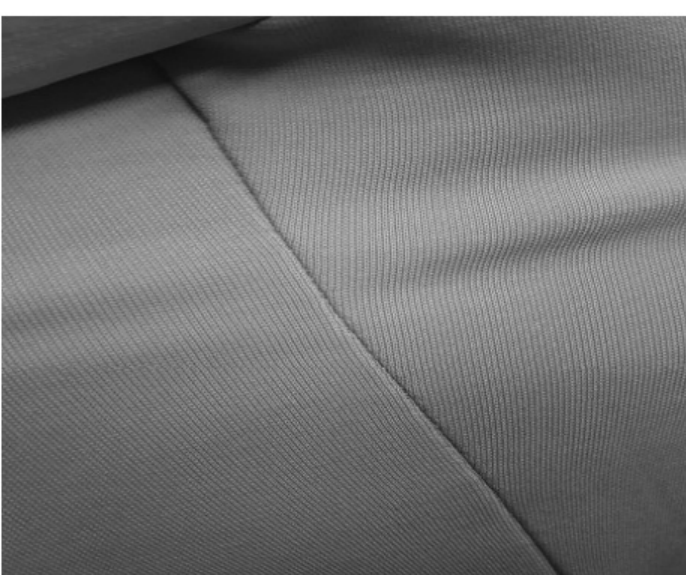

Figure 5: Sample sewn according to the new machine settings 
Table 4: Check list of registered defects in the final control

\begin{tabular}{|c|c|c|}
\hline Type of defect & $\begin{array}{c}\text { Total } \\
\text { frequency }\end{array}$ & $\begin{array}{c}\text { Defects occurrence in the total number } \\
\text { of manufactured } \\
\text { pieces (\%) }\end{array}$ \\
\hline Missing label (operation 7.6) & 2 & 0,19 \\
\hline Missing label (operation 7.7) & 3 & 0,28 \\
\hline Badly ironed seams (operation 7.2) & 2 & 0,19 \\
\hline Uneven width of the hem (operation 7.10) & 5 & 0,37 \\
\hline Glaze from ironing & 4 & 1,49 \\
\hline Total & $\mathbf{1 6}$ & $\mathbf{1 , 4 9}$ \\
\hline
\end{tabular}

\section{CONCLUSION}

From the obtained results can be concluded that the inter-phase control can contribute to improve the course of the production process, in the meaning to provide a stable and no defective flow.

According to the results in the first manufactured module several defects were detected, which reduced the value of the product, and represented potential complaint by customers.

The largest percentage of registered defects in the first manufactured module, as much as $75 \%$ belong to the defect holes on the side seam, which occurs at the preparation of the technological operation under serial number 7.1.

Applying the Ishikawa diagram were detected the reasons (factors) for this defect occurring. According to the results from the Ishikawa diagram it was concluded that one of the possible factors that have impact of the defects occurring was the machine, respectively adjustment and needle. That means that was made the wrong choice of needle size as well as the wrong choice of transport gears during machine setup.

To test whether the wrong choice of needle size and the wrong choice of transport gears are the main causes for the defect (holes in the side seam), new samples were sewn.

The type of needle was changed- the previously used needle numeration $\mathrm{Nm} \mathrm{75/11}$ with normal conic head was replaced for a needle with a medium sphere head and numeration $\mathrm{Nm}$ 65/9.

The transport gears with higher density and lower inclination were also applied, so the number of defects was reduced.

For the other defects occurring, it was noticed that the main cause is the man, which indicates that the line controllers should pay more attention in controlling operators who are working on these operations, to achieve a stable and quality course of the production process without variations for defects repair.

With the application of inter-phase control the number of defects began to decline, and this reflects in the final control results, indicating a stable process, with $1.49 \%$ defective products. This means that the goal has been achieved, the quality is satisfactory, and operating losses due to poor quality were minimized.

\section{REFERENCES}

[1] Krishna, B. Misra. (2008). Quality Engineering and Management (Handbook of Performability Engineering. Springer Verlag, London. 157-170.

[2] Juran, JM., Gryna Jr. FM. (1980). Quality planning and analysis. 2nd edition, McGraw-Hill, New York.

[3] Чепујноски, Ѓ. Чепујноска, В. (1993). Управување со квалитетот во практиката. Скопје.

[4] Hakes C. (1991).Total quality management: A key to business improvement. Chapman \& Hall, London.

[5] Cottman. Ronald, J. (1993). Total engineering quality management. Marcel Dekker. New York.

[6] Wood, M. (2002). Understanding, Managing and implementing Quality. Routledge, London. 103-119.

[7] Sorak S., Urošević S., Sorak M. (2017). Uticaj ponašanja rukovodilaca-menadžera na uspešnost poslovanja preduzeća tekstilne industrije u Banjoj Luci. Tekstilna industrija, 65(2), 40-47.

[8] Ќортошева, С. (2002). Анализа на трудот во конфекциско претпријатие. интерна скрипта, ТМФ-Скопје.

[9] Mehta P. V., Bhardwaj S. K. (1998). Managing quality in the apparel industry, Nacional institute of fashion technology, 235- 243.

Rad primljen: 01.05.2020.

Rad prihvaćen: 01.06.2020. 